\title{
Multilingual Practices AND Linguistic CONTACTS IN PRE-PATRICIAN IRELAND AND LATE ROMAN BRITAIN
}

\author{
MAXIM FOMIN
}

\section{Introduction}

What kind of contact and exchange was known to exist between the Roman world and the island of Ireland in the pre-Patrician period? This necessarily short contribution will try to answer this and the following questions that emerge as a result of this inquiry. Do we have any evidence of archaeological, toponymic and palaeographic nature that argues in favour of the contact? Can one find any evidence of the linguistic contact? What kind of words entered Early Irish from Latin in this period? How do we address and interpret the instances, variations and patterns of Irish/Latin code-mixing and diglossia in the earliest documents, such as the Leinster genealogies, the early sections of the glossaries and of the annals (c. 440-470 AD)?

Various scholars (Mohrmann 1962: 217; Ó Cróinín 2004: 8; Harvey 2011: 66) have argued that Latin, introduced as "an artificial, bookish language, distant from the dimension of everyday communication" (cit. in Bisagni 2014: 53), was alien to the Irish in its form and essence so that it was used purely for monastic purposes. I will argue against this, proposing a contrary argument: the Irish were at home with Latin, and gained their knowledge of the language through their communication with the Roman world through warfare and trade.

\section{Pax Romana and Ireland}

A recent study by the Marburg historian Patrick Reinard (2014) entitled 'Arma ultra litora Iuvernae promovimus - Römer in Irland?' re-visited the long-accepted view based on the information conveyed by the Roman authors Juvenal and Tacitus that Roman presence in Ireland was always excluded. In his opinion, the military campaign to invade Ireland would have been too costly, and unnecessary in the absence of any clear economic or military benefits. He argues that the Romans organised socalled 'Erkundungsfahrten' - reconnaissance trips - to examine the Irish land and its people, as well as its economic, military and political potential, but that the military threat of Ireland to the Roman empire was 
ultimately considered too low to carry out a military expedition of any sort. The key passage in Tacitus is carefully examined:

si quidem Hibernia... si Britanniae comparetur, angustius, nostri maris insulas superat. solum caelumque et ingenia cultusque hominum haud multum a Britannia different [in melius] aditus portusque per commercia et negotiatores cogniti.

inasmuch as Ireland...its extent is small when compared with Britain, but exceeds the islands of our seas. In soil and climate, in the disposition, temper, and habits of its population, it differs but little from Britain. We know most of its harbours and approaches, and that through the intercourse of commerce.

(trans. John \& Brodribb 1942, chapter 24.2) ${ }^{1}$

He provides arguments in favour of the established trade relations between the Roman province of Britain and Ireland since the middle of the $1^{\text {st }}$ century AD (ibid., 21-3) and, what is more, that the Romans could have had a continued presence on the islands of Drumanagh and Lambay, located north of Dublin, employing them as trading outposts. It cannot be confirmed whether Drumanagh could be identified with Ptolemy's Manapia, ${ }^{2}$ and whether Lambay is identical with Ptolemy's Limnos, ${ }^{3}$ however, discussing late $1^{\text {st }}$ - early $2^{\text {nd }} \mathrm{cc}$. $\mathrm{AD}$ finds from these islands, various scholars (Rynne 1976; Raftery 1994: 200; id. 1996) argue that these were inhabited by the North Britons whose material culture was strongly influenced by Rome. It is still not clear whether the 40 -acre "iron age promontory fort" at Drumanagh was a civil trade centre ("einen zivilen Handelsstützpunkt", Reinard 2014: 21) or a bridgehead for the Roman military campaign across the island.

Reinard's view accords with that of T. Charles-Edwards (2000: 156) who speaks of the Roman merchants getting access to Ireland at

\footnotetext{
${ }^{1}$ Reinard suggests a different interpretation of the last sentence: "the approaches and ports are better known through trade and [by] merchants (than the interior of Ireland)" (2014: 6, fn. 29).

${ }^{2}$ And whether the Menapian soldiers who were stationed in Britain (Spaul 2000: 174.185, cohors I Menapiorum nautarum) had any connection with it. Di Martino (2003: 32) and Warner (1995: 26) are in favour of this hypothesis. Toner (2000: 79) cautions that "none of the settlements or promontories have been securely identified". Following O'Rahilly (1946), Mac an Bhaird (1991-3) and Pokorny (1954), he identifies the tribe of Manapioi as 'Monaig' and locates them in Fermanagh, SW Ulster. Warner (1995: 26) notes that "the Irish tribe of Manapii and the town of Manapia are placed very firmly by Ptolemy south of Dublin bay".

${ }^{3}$ Identified as such by Warner (1995: 26). No data provided by Toner (2000: 82) for the island of Limnos. He, however, identifies the island of Rikina with the Rathlin Island (Ir. Rechru, Rechrainn). Note that the Ir. name of Lambay is also Reachrainn.
} 
nexus points, "sometimes called 'gateway communities' [...] known in the seventh and eighth centuries as emporia."

One site that has been suggested as having such a role is Dalkey Island, at the southern end of Dublin Bay. Another may have been found at Drumanagh, near Loughshinny, on the coast north of Rush, Co. Dublin [...]. By the seventh and eighth centuries, if not earlier, there may have been another at Colp near the mouth of the Boyne. ${ }^{4}$ Emporia within this central span of the east coast would account for the concentration of Roman finds in what was later known as Brega.

It is important to point at the find of a Roman naval vessel, "a typical product of the Mediterranean tradition of shipbuilding", known as the 'Monk's Boat' from Loch Lene, Co. Westmeath, of "not later than the fourth century AD and probably earlier" dating (Brindley \& Lanting 1990: 11). The scholars point out that

only five boats $[\ldots]$ constructed in this manner have been found north of the Alps, all in provincial Roman contexts [...] the Loch Lene vessel is smaller than the other five [...] probably because it was used for shortdistance inland commuting. The boat itself can be considered on the basis of its construction and rarity as arguably either a Roman import or built by someone from the Mediterranean ship-building tradition, i.e. a Roman settler in Ireland.

$(\text { Ibid. })^{5}$

The above-mentioned evidence argues for the strong trade connections between the Roman world and Ireland. These connections were

\footnotetext{
${ }^{4}$ Charles-Edwards (2000: 156) points to the evidence of Muirchú's Vita S. Patricii I 14(13). Eleuata igitur nauis ad mare... in portum hostii Colpdi bene et prospere delati sunt, "they set their ship afloat... and after a good and calm voyage they landed at Inber Colpdi' (Bieler 1979: 84-5). A vernacular, rather than a Hiberno-Latin, source speaks of ships arriving at the same port of Colp as one of the blessings of the righteous rule: uii. mbárca cach mís mithemon da gabáil oc Inbiur Colbtha cach bliadna, 'seven ships every month of June to arrive (?) at Inbhear C. every year' (Togail Bruidne Da Derga §17.183-4, Knott 1936: 6), also arguing for this port's provenance in the late $7^{\text {th }} \mathrm{c}$. AD Ireland.

${ }^{5}$ Bockius (2011: 31, fig. 13) provides a map of the locations where such barges (or 'scows': the scholar uses the term 'Prahm' to designate this type of a naval vessel) were found and provides his analysis of the finds from Châtenay-Mâcheron and Laibacher Moor (figs. 14a, 16a). He argues that such boats came in the train of the Roman occupation of the areas and presented a technological innovation with regard to the naval vessels previously used, with its roots in Italy or in the Mediterranean, pointing to Massillian influence. Thus, one can be safe in assuming that we are dealing here with the evidence of Roman presence in Ireland.
} 
established by the Roman merchants to Ireland long before the invasion of Britain under Claudius in $43 \mathrm{AD}$. We are informed of the writings of Philemon who probably consulted such merchants ${ }^{6}$ and provided a detailed account of "the sea routes around the island, the names of places and tribes, and roughly the distances from the ports to the strongholds of the tribal chieftains" (Toner 2000: 73). On the other hand, the Irish mariners were well informed of the wealth of the British coastal ports, having primarily benefited from trade in the period of late Roman Britain. Beside trade, there were Irish military expeditions, details of which are provided, for example, in the historical work of Ammianus Marcellinus. As a Roman army officer and a contemporary, he writes about the attacks by the Scots and the Picts on Britons: ${ }^{7}$

[T]he ability to mount major sea-borne attacks across the Irish sea suggests that the Irish had previously, during the peace broken in 360 , invested heavily in ships [...]. The Irish shipping that existed by 360 may, therefore, have played a part in ensuring that the Irish had access to the greater prosperity of Britain in the fourth century.

(Charles-Edwards 2000: 157)

Returning to Ireland, let us surmise that the foundation of such trade outposts as Drumanagh and Lambay, together with possible contact between the foreign visitors and the local inhabitants using the coastline and the inland water routes, argues in favour of active commercial interaction between Roman Britain and Ireland since at least the $1^{\text {st }} \mathrm{c}$. AD. ${ }^{8}$ However, as no trade may exist without both parties in the exchange

${ }^{6}$ Philemon's work was consulted by Marinus of Tyre who was the major source for Ptolemy's description of Ireland. Because a number of Irish names such as these appear in Ptolemy showing British characteristics, scholars attributed them to the informants that supplied information to Philemon, who, most likely, were British merchants trading with the south-east coast of Ireland (Toner 2000: 73; Mac an Bhaird 1991-3: 1; Raftery 1994: 206).

${ }^{7}$ Consulatu vero Constantii deciens, terque Iuliani, in Britanniis cum Scottorum Pictorumque gentium ferarum excursus, rupta quiete condicta, loca limitibus vicina vastarent, et implicaret formido provincias, praeteritarum cladium congerie fessas 'But in Britain in the tenth consulship of Constantinus and the third of Julian raids of the savage tribes of the Scots and the Picts, who had broken the peace that had been agreed upon, were laying waste the regions near the frontiers, so that fear seized the provincials, wearied as they were by a mass of past calamities' (Ammianus Marcellinus, Res Gestae, ed. \& trans. Rolfe 1935-40, cap. XX.1.1).

${ }^{8}$ Although they are of a later date, one should not disregard the evidence of the early Irish wisdom-texts concerned with ideal kingship: "there is an interesting association of trade with the rule of the ideal king" (Breatnach 2014: 8). One should recall that the Audacht Morainn (Rec. A), compiled in the first third of the $7^{\text {th }} \mathrm{c}$. AD, speaks of tromliberna lán [a] mban, mór maine, mór mbárc, 'heavy ships, plenty of women, abundance of treasures, 
sharing a common language, our next step is to look at the linguistic data that permit us to argue in favour of early language contact and exchange between post-Roman Britain and pre-Patrician Ireland. ${ }^{9}$

\section{Linguistic borrowings from Latin in pre-Patrician Ireland}

The question of bilingualism in the Roman world has been extensively studied, confirming that different languages continued in use alongside Latin: their presence is revealed by chance intrusions into the documentary evidence.

On the other hand, the influence of Latin on the vernacular languages may not be discussed without considering the special connections between Latin and other IE languages. The IE language groups which we know to have been spoken adjacent to the Latin speech area in historic times are Germanic, Greek and Celtic, of which the latter two are the closest. The features shared by Latin and Greek reflected common inheritances from the parent language, whereas those between Latin and Celtic gave birth to the so-called Italo-Celtic theory (though later scholars are divided in their assessment of the evidence used to support it). ${ }^{10}$

It is possible to propose an argument that some unique morphological features shared by Latin and Celtic arose due to language contact. Thus, a gen. sg. marker $-\bar{l}$, characteristic of Latin and Primitive Irish (Ogham maqqi 'of the son') arose relatively late in Latin and Celtic, c.300 BC, as it replaced the ending -oiso found in the earlier $400 \mathrm{BC}$ Lepontic inscriptions

abundance of ships', and the $9^{\text {th }} \mathrm{c}$. AD Tecosca Cormaic lists bárca do thochor, allmuire sét, 'ships arriving, foreign goods of value' (ed. \& trans. Fomin 2013: 211). "These statements find a close parallel in the seventh-century Munster law text Cáin Fhuithirbe, in a part of the text concerning the rightful king [...] trīa fholta-som .i. mā dagfolaid do-berat longa lüatha fairce 7 bärca gona mbrīg 'through [him fulfilling] his obligations, i.e. if he has fulfilled them well, they bring swift seagoing ships and barks with their strength"" (Breatnach 2014: 9). Breatnach also notes that although "prosperity through trade is seen as a sign of rightful rule, a major problem is that the law texts [...] have very little to tell us about trade and merchants [...] their apparent absence in these texts" (ibid.). Note however a reference to the presence of foreign tradesmen in Ireland in the Metrical Dindshenchas, which could be an echo of such commercial intercourse. In the dindshenchas of Carmun, $\$ 77$, lines $305-8$, among the three kinds of markets current in early Ireland, there is a mention of "the great market of the Greek foreigners, where were gold and fine raiment" (marggad mór na nGall ngrécach i mbíd ór is ardd-étach, Gwynn 1906: 24-5).

${ }^{9}$ For a fresh overview of the recent findings on the contact between Ireland and the Roman world, see now Johnston (2017).

${ }^{10}$ See, inter alia, Vendryes (1913) and Dillon (1944). The latest treatment of the theory is in Weiss (2012); the main features of the Italo-Celtic hypothesis are given in Weiss (2009: 465-6). Schrijver (2016) discussed phonological innovations shared by Italic and Celtic, and argued "for an Italo-Celtic node on the Indo-European family tree", suggesting "that the two language groups were spoken in geographical proximity" (ibid., 499). 
(Eska \& Wallace 2001: 80; replaced by $-i$ in the later) and the ending -osio (attested as a genitive singular) in early Faliscan and Latin inscriptions (i.e., the so-called Lapis Satricanus inscription) $<*^{*}$-osyo as reconstructed from Greek and Sanskrit. "The common gen. sg. ending may therefore be an example of a borrowed inflectional morph between closely related languages" (Clackson \& Horrocks 2007: 32). An independent study by Ringe, Warnow \& Taylor (2002) provided an argument for a close relationship between Italic and Celtic that share four features to the exclusion of other IE subgroups that include the phonological change of ${ }^{*} p V k w$ to ${ }^{*} k w V k w$ (i.e. Lat. quinque, OIr. coic < *penkwe ' 5 '), ${ }^{11}$ the productive suffix *-tion-, the word for lake *loku-, the verb 'to sing' *kan-.

Ringe, Warnow \& Taylor (2002: 100f.) argued that "these agreements arose through very early contact between the ancestor of Latin and the Celtic languages, continued through the common presence of both branches" (cit. from Clackson \& Horrocks 2007: 34) in proximity with each other. ${ }^{12}$

As far as Roman Britain and pre-Patrician Ireland are concerned, language contact between the Britons and the Irish would often be facilitated by the presence of Latin in Britain as an official language; however, contact was also established by the insular Celtic speakers without recourse to Latin. Matasović (2007: 95) notes a number of Goidelic loanwords in British and vice versa, pointing out that in the linguistic situation where "two languages in contact are of radically unequal status $[\ldots]$ borrowing of lexical material from the higher variety into the lower one can [be of] massive proportions":

In Early Britain and Ireland, after the withdrawal of the Roman legions in 410 A.D., the dominant type of bilingualism seems to have been one in which at least Goidelic and British were idioms of roughly equal status. Code-switching must have been frequent, as well as exogamy, with children growing up in mixed marriages speaking early forms of British and Goidelic, and in some cases also Vulgar Latin, equally fluently.

(Matasović 2007: 95)

\footnotetext{
11 See a more extensive list in Schrijver (2016: 490-5) who discussed fifteen sound changes found only in Italic and Celtic.

12 One should take into account the study by Russell (1990) in relation to the effect of Latin on the derivational patterns of the insular Celtic, noting parallels between the GalloLatin pattern of adding -(i)acum to personal names (he explains this as "a Gaulish innovation making use of a native suffix added to Roman personal names", Russell 1990: 53) and the late Brittonic pattern of adding a hypocoristic -og to such names of the -iostem. Likewise, "most of the -ol derivatives have been influenced by the parallel Latin suffix -alis, a connection between Welsh -ol and Latin -alis was perceived at an early stage in Welsh and was effective in the creation of derivatives based on Latin loanwords" (ibid., 128-9).
} 
Historical ${ }^{13}$ and toponymic evidence $1{ }^{14}$ as well as the data of the literary sources ${ }^{15}$ and bilingual inscriptions ${ }^{16}$ speak in favour of the existence of Goidelic speaking communities in Wales as early as at least the $5^{\text {th }} \mathrm{c}$. AD due to the external expansion of the Leinster dynasties across the Irish sea. Likewise, one can safely postulate the existence of British-speaking communities in Ireland. ${ }^{17}$

Taking into account this information, we can now look at the question of the linguistic contact of the Irish with Latin in the prePatrician period and the influence of Latin on the Irish lexicon. J. Carney (1971) was the first to systematically look at the earliest borrowings into Early Irish from Latin in the spheres of warfare and seafaring. His observations were followed by the detailed studies of McManus (1983) and Russell (2005). According to McManus (1983: 43, fn. 50), "most of the words listed, all of which are found in the Leinster Poems ${ }^{18}[\ldots]$ show 'a non-Christian Ireland, having very close contact with and knowledge of

13 T. Charles-Edwards (2000: 157-63) argues for the existence of confederations of Irish tribes that were interested in expansion and "a need for land must also be part of the explanation [...] a need on behalf of the kings and nobles for land to sustain their rank" (ibid., 161). Snyder (2003: 192 ff.) points to the Irish names in the regal lists of the kingdoms of Gwynedd and Dyfed.

${ }^{14}$ See Richards (1960) on the study of topography of the South-West Wales which also confirmed the Christian character of the local monuments bearing Irish names.

15 The early medieval kingdom of Dyfed, originally founded as the Romano-British civitas of Demetae, was ruled by an Irish dynasty "from at least the sixth century until the ninth" (Charles-Edwards 2000: 163). The literary sources where the story of the dynasty is told include Tairired na nDésse ('Expulsion of the Desi'; see Ó Cathasaigh 1984, 2005) and, indirectly, Sanas Cormaic (Meyer 1912, no. 883).

${ }^{16}$ Charles-Edwards (2000: 164) points to the Latin-Irish inscription at the Castelldwyran church, "in the heartland of early medieval Dyfed", commemorating the local king Voteporix (analysis in Hamp 1996). Matasović (2007: 95) discusses the Latin-Irish Ogham inscriptions of the area and cites Jackson (1953: 153-4) who provides evidence for the whole of Britain: "two [Ogams] in Argyllshire opposite north-eastern Ireland, six in the Isle of Man, forty in Wales, six in Cornwall, two in Devon, and a stray at Silchester in Hampshire; a total of fifty-seven, of which forty-four are accompanied by a Latin inscription".

${ }^{17}$ Dumville (1993: 138) speaks of the $5^{\text {th }} \mathrm{c}$. AD British Christian missionaries; evidence of St. Patrick's letters is in favour of the recurring presence of the British warlords on the island of Ireland (Hanson 1971); note also a vague recollection of the mission of Isernius to the south of Ireland in the Additamenta to the Tirechán's Vita S. Patricii (Bieler 1979: 174-5). Matasović (2007: 96), following de Bernando Stempel (2000) refers to Ptolemy's record of British place-names and tribal names in Ireland, but in view of Toner's (2000: 73 ) argument (see fn. 5 above) this view cannot be supported.

18 "When these poems are re-edited, the ancient nucleus will, I think, provide something very close to contemporary documentation for the Laigin and their enemies in the years separating Cathair Már (c. 400) from Nad-Buidb and Eochu son of Énna Censelach (c.480$500)$ politically $[\ldots]$ a dynastic group in Leinster $[\ldots]$ given to overseas raiding, extending as far as Gaul, and are very conscious of Roman civilisation" (Carney 1971: 73). 
the Roman empire'". These are EI arm 'armour' < Lat. arma, EI míl, cathmilid 'soldier' < Lat. miles, EI bárc 'bark, ship'< Lat. barca, EI long $<$ Lat. (navis) longa, EI múr 'wall of a rampart' < Lat. murus, EI drauc 'dragon' > Lat. draco, EI gríb 'griffin' < Lat. gryphus, EI léo 'lion' < Lat. leo, EI Mercúir 'Wednesday' < Lat. (dies) Mercurii, EI Saturn 'Saturday') $<$ Lat. (dies) Saturni, EI cland 'plant, off-spring' < Lat. planta, romdae 'Roman' < Lat. Romanus, EI ór 'gold' < Lat. aurum, EI trebun 'chieftain' $<$ Lat. tribūnus, ${ }^{19}$ EI Gall 'a Gaul' < Lat. Gallus, EI Alpión 'Alps' < Lat. Alpes/Alpium. Intriguingly, the EI claidem 'sword' ( $>$ Lat. gladius) ${ }^{20}$ and EI sciath 'shield' ( $>$ Lat. scutum) $)^{21}$ may provide examples of linguistic borrowings in the opposite direction.

Most of these words borrowed into Early Irish were transmitted orally: they reflect sound-changes in Irish subsequent to their arrival (Russell 2005: 437). Russell argues for the use of Latin, along with Irish, in Ireland since the $4^{\text {th }} \mathrm{c}$. AD onwards. He alludes to the examples of loanwords contained in Cormac's Glossary that provide indications of established language contact: much of the material in the glossary derives from pre-existing glossary collections and thus provides us with a glimpse of quite an early stage of the language.

The Irish were aware of borrowings not only from Latin, but also Greek, Hebrew (and even Pictish!), yet they explained them in terms of language contact, borrowing and 'corruption' rather than parallel genetic developments from a common ancestor.

"Latin words borrowed into early Irish can take on more than one form, depending on the date of their arrival" (Russell 2005: 436). One of

\footnotetext{
${ }^{19}$ By analogy, OI centúir, cetuir, 'centurion' found in Rawl. B 512's treatise on the Roman realm may also have been borrowed into the language with other terms of Roman provenance in the pre-Patrician period: Flaithius Róman, tra, ise flaithes deginach a ceimendaib ar imat a consal ocus a conditore ocus a legaite ocus a coimite ocus a ndictodoire ocus a patrici a patrapas [leg. satrapas] ocus a lataire ocus a ndiuce ocus a centure, 'The realm of the Romans, now, it is the last realm of the world, and it is impossible to reckon their ranks and their steps because of the multitude of their consuls and their founders and their legates and their counts and their dictators and their patricians, their satraps, and their legislators (?), and their judges (recte war leaders) and their centurions' (ed. \& trans. Stokes 1887: xxviii).

20 This etymology is already attested in an Old Irish Glossary from H.2.13 (DIL s.v.; Stokes 1860, item 461); P.W. Joyce reports "claidheamh [cleeve], old Irish claidem, obviously cognate with Lat. gladius; Fr. and Eng. glaive; which is still well known in the Scotch claymore, i.e. claidheamh-mór, 'great sword' (Joyce 1912: 180). Matasović (2009: 205) links OIr. claideb < *kladiwo- 'sword' to the "Brittonic words (MW cledyf, MBret. clezeff, Co. clethe) [that] are early loanwords from Goidelic. It is usually assumed that Lat. gladius was borrowed from Celtic in prehistoric times, but it could also be inherited".

${ }^{21}$ Ivanov (1999: 185) indicates that Lat. scūtum 'big square shield' derives from OIr. sciath due to a late reflex of the palatalised $s c$ - in front of $-i$, and provides an Old Church Slavonic schit 'shield' as a further example of this development.
} 
the most important words, imported from Latin into Irish and in two different forms was the personal name Patricius > OI Cothriche and Pátraic. Both were invoked in the twentieth-century academic scholarship as the headings of the two groups (the earlier Cothrige series and the later Pátraic group) of the Latin loanwords into Irish.

According to McManus (1983: 29), the words of the so-called Cothrige series, including OI cuithe 'pit' < Lat. puteus and OI cland 'offspring' < Lat. planta, as well as OI senester 'window' $<$ Lat. fenestra, OI $\operatorname{sorn}(n)$ 'oven, kiln, furnace' < furnus, OI sléchtaid 'kneels, bows down' < Lat. flēcto, OI síbal 'buckle' < fïbula, OI sroigell 'scourge' < Lat. flagellum, OI seib 'beans' < Lat. faba, OI srían 'bridle' < Lat. frènum, OI súst 'flail' < Lat. fústus, have been borrowed between 450-500 AD into Primitive Irish.

Apart from a purely ecclesiastical lexicon which exhibited the influx of terms to do with the introduction of Christian religion and doctrine into Early Irish tradition from the year $450 \mathrm{AD}$ onwards, McManus (1983: 43) refers to an exhaustive list of borrowings "associated with trade, especially of wine": EI fin < Lat. vinum, EI corcur 'purple dye' < Lat. purpura, EI sesra 'a measure of capacity' < Lat. sextārius, EI muide 'a vessel for holding liquids' < Lat. modius, EI esarn 'year-old wine' < Lat. exhibernum (vinum), EI creithir 'container, vessel' $<$ Lat. creterra/crātera, EI cann 'vessel' < Lat. panna, EI sithal 'vessel for drawing water' < Lat. situla, EI cess 'basket' < Lat. cista, EI ingor 'anchor' < Lat. ancora, EI cróch 'saffron, dye' < Lat. crocus, EI monad? 'money' < Lat. monēta, EI dírna/dinnra 'weight' < Lat. dēnārius.

The use of the lexical items cited above is not only confirmed by written documents: it is supported by the abundant archaeological evidence of active trade routes. These ran between, as we have already mentioned, Roman Britain and the south of Ireland, and also - of equal importance - between the Mediterranean Europe and Ireland (Raftery 2005: 175-9). Such items may have been borrowed into the language before the arrival of Christianity to Ireland, yet McManus states that "there is nothing inherently unchristian about them" (1983: 43).

In the first section of the article, following Charles-Edwards (2000: 156), I recalled the existence of trading ports, the so-called emporia, on both sides of the Irish Sea where any commercial exchange between the Irish and the Roman British was protected by mutually binding treaties. One can point to the evidence of Old Irish that testifies to the existence of such centres: OI calad (< Low Lat. calatum, 'port, shore, landing place', Romance *calatum; Ital. calata, Fr. Cale). O'Curry (1873: I.21) refers to the second book of Ptolemy's Geographia on Britain ('Albion'), that mentions the towns (poleis) of the Brigantes, among them Kálaton or 
Calatum. ${ }^{22}$ Other words from a purely commercial lexicon that were probably borrowed in the pre-Patrician period include OI callait 'clever, cunning' ${ }^{23}$ and OI legáit 'envoy, ambassador'. ${ }^{24}$

\section{Code-switching: Latin in Early Irish genealogies, glossaries and annals}

Proinsias Mac Cana (2011: 47), writing on cultural diglossia in early medieval Ireland, draws attention to "the disparity in the cultural provenance of the two languages, Irish and Latin", putting the two languages in contrast with one another - Latin being foreign and innovative and Irish being native and conservative. The view that Latin was alien to the Irish has been supported by a number of scholars who, assessing the parallel existence of Latin writing and the vernacular Irish learned tradition, tried to downplay the fluency with which the Irish literati were at home with the Latin language. ${ }^{25}$ Writing about his experience of compiling the Additamenta to Tirechán's Life of St. Patrick in the Book of Armagh, Ferdomnach complains of the necessity of

\footnotetext{
${ }^{22}$ Toner (2000: 78) points to the existence of Brigantes in the south-east of Ireland as well as south of the Hadrian's Wall in Britain, yet says that their name has no "credible reflex in any Irish tribal name". Old Irish calad is found in Aided Guill mac Carbada: Goll, the warrior from northern Germany, when asked by Cú Chulainn not to come back to Ireland, na gaibed i n-airiur do aireraib Herenn din chursa 'do not approach into any shore of the shores of Ireland of your course', is addressed by Cú Chulainn's charioteer, Loeg: na taisc do churach co calad do chaladaib Herend, 'bring not your boat near to any port of the ports of Erin' (LL 12698, Stokes 1893: 408.17).

${ }^{23}$ Based on the Lat. callidus, the word is glossed glic 'clever' in Cormac's glossary; O'Mulc unequivocally indicates its Latin derivation: callaid gl. a kallido, 197. A Latin dictionary explains the meaning of the word (in negative or neutral meaning) as versutus (virum versutus - Odysseus) 'wily, full of stratagems', dolosus 'sly', astutus 'cunning, crafty'; (in positive meaning): peritus 'skilled', sollers 'intelligent', prudens 'sensible, clever' (Lehmann 1968: II.1 s.v.). In this word, one finds a human quality so important for commercial operations and trade. Another archaic borrowing of commercial nature which is however difficult to date is OI meirse < Low Lat. mercia in the meaning 'a fine, amercement': méirse gl. amerciamentum (Stokes 1860: Item 780).

${ }^{24}$ Derived from Lat. legatus, early examples of its usage in Irish are found in the Féilire Óengusso: Gallicanus .i. leghait do rig Roman tainic co tir Frangc, 'G., legate to the king of Rome came to the land of the French' (Stokes 1895: $158 \S 26$ ); however, its meaning here is ecclesiastical. For non-ecclesiastical usage of the term in OI, see Rawl. B 512's treatise on the Roman world, fn. 16 above.

${ }^{25}$ Thus, Mohrmann (1962: 217): "in Ireland Latin was introduced as the language of the Christian Church and of the Latin civilization introduced by Christian missionaries, without being adopted as the current language of everyday life"; Ó Croinín (2004: 8): "[...] for them [the Irish] Latin was an alien language. Never having been part of the Roman Empire, the Irish acquired their knowledge of Latin at second hand, from books"; and Harvey (2011: 66): "to the early medieval Irish, Latin was an entirely foreign language, which they had to learn from books".
} 
undertaking such an exercise through the medium of Old Irish rather than Latin:

Finiunt haec pauca per Scotticam inperfecte scripta, non quod ego non potuissem Romana condere lingua, sed quod uix in sua Scoti $<c>a$ hae fabulae agnosci possunt; sin autem alias per Latinam degestae fuissent, non tam incertus fuisset aliquis in eis quam imperius, quid legisset aut quam linguam sonasset pro habundantia Scotaicorum nominum non habentium qualitatem.

[IX 2] 17. (1) Here end these few pieces, written imperfectly in Irish. Not that I could not have penned them in the Roman language, but these stories are hardly intelligible even in Irish; had they, on the contrary been told in Latin, one would not so much have been uncertain about them as left in the dark as to what one had read and what language had been used because of the great number of Irish names which have no established forms.

(Bieler 1979: 178-9) ${ }^{26}$

Rather, the evidence collected by Harvey (1999: 56), speaks in favour of an opposite practice: "Adomnán [...] a native speaker of archaic Old Irish, wrote a Life of Columba that contains hundreds of names translated into Latin from his native language $[\ldots]$ the Latinising habit is the rule rather than the exception". Harvey explains this due to the perceived high status of Latin in the Middle Ages as compared with the vernacular.

I am inclined to carry this argument further. The historical and archaeological evidence provided above speaks in favour of the networks of exchange that existed between pre-Patrician Ireland and Roman Britain epitomised in the trade centres ('emporia') on both islands where Latin was probably used as a lingua franca, along with the two (or more) vernaculars. The ease with which Christian missionaries move across the Irish Sea and to the continent in the $5^{\text {th }} \mathrm{c}$. $\mathrm{AD}$, argues at least in favour of the fact that the Irish monastics were capable of using Latin as an everyday language on their travels. ${ }^{27}$ Arguments in favour of Latin being a spoken language in Ireland have been put forward by Bisagni (2014: 7),

\footnotetext{
${ }^{26}$ Bieler dated the colophon to $c .700$ AD (1979: 246). Bronner (2005) gives a study of Latin/Irish code-switching in late ninth-century Ireland on the basis of the Vita Tripartita Sancti Patricii.

${ }^{27}$ I refer to the early documents by St. Patrick. In his Confession and Letter to Coroticus, the saint does not seem to be "lost in the language". On the contrary, he demonstrates a perfect ability to communicate with people of different social standing and nationalities, be they the sons of the Irish princes who guard him on his mission throughout Ireland, the Irish pirates who capture him in his youth, or a British war-leader whom he addresses in the latter document, and it is clear that he uses Latin as a linguistic medium to be understood.
} 
on the basis of the research done by McManus (1983), J.-M. Picard (2003) and others. ${ }^{28}$

This foundation provides us with a different perspective on how to access the evidence of the data in which Latin and Early Irish are found side by side within the confines of one inscription, document or compilation. While "the use of Latin and Irish in the same text is a very frequent phenomenon in medieval Irish sources" (Bisagni 2014: 16), it is important to note such a practice and call the reader's attention to the earliest examples where it can be found.

The Ogam inscriptions in Britain set the scene. McManus (1991: 61) speaks of approximately forty items, of which two have independent Irish and Latin inscriptions and twenty-eight he describes as bilingual. ${ }^{29}$ The differences between Irish and Latin are due to morphological adjustments (inscription 362: "the imitation of the Latin filia with the Irish nominative inigena", McManus 1991: 63; cf. also inscription 449, where the Lat. fili is imitated with the Ogam genitive maqi), Latin inscriptions look sometimes longer than the corresponding Ogam in their addition of the phrase hic iacit. The formula originated in Italy in the $4^{\text {th }} \mathrm{c}$. AD (NashWilliams 1950: 8) and its presence in the British Ogams provides "a link between their Irish counterparts and Gallic funerary customs" (ibid., 62). McManus (1991: 63) adds:

If some scholars have regarded the Latin inscriptions accompanying the Ogams as secondary in nature, designed for the benefit of native Britons who could not read the Ogam script, the single-name Ogams with more detailed Latin legends appear to suggest that the opposite was in fact the

\footnotetext{
${ }^{28}$ See also Harvey 2013: 9. This proposal should not be taken as an argument against the importance of the influence of Latin within the confines of the written medium. In fact, a number of Latin loan-words into Old Irish that belong to the domain of the scriptorium point to the primary role of the Latin learning in the formation of the Irish written tradition. Such examples include OI scíam < Lat. scèma 'figure of speech' (in sciám arafoimsom 'the figure that he adopts' gl. scema M1. 29a3, Stokes \& Strachan 1901: 60) and OI * dechtaid < Lat. dictare 'composes', attested in Cogitosus' writing in the form of a part. nec. in budh laedh bo deachtaidhe dóibh 'a poem should be made for them,' Cog. 98. 9; cf. also a compound do-er-dechtim, gl. dico dicto (Sg 155 4 , Stokes \& Strachan 1903: $163)$.

${ }^{29}$ See fn. 13 above for their exact locations as informed by Jackson 1953. McManus (1991: 62) reports that "the importance of these inscriptions cannot be overstated. They constitute valuable contemporary evidence for the existence and distribution of Irish settlers in western Britain in the fifth and sixth centuries of our era [...] In this they are complemented by a number of non-Ogam inscriptions bearing Irish names [...] as well as by some features which may stem from Irish practices, such as the son $\mathrm{X}$ of the $\mathrm{Y}$ formula, the preference for the genitive construction and the vertical disposition of inscriptions on memorial stones".
} 
case, i.e. that the Ogam was considered secondary and complementary and might be abbreviated and modelled on the Latin.

Secondly, we draw the reader's attention to the earliest Irish "surviving verses $[. .$.$] , found in the Leinster genealogies; these are in primitive$ accented metres, and some may date from as early as the fifth century" (Carney 2005: 458). A careful look at the manuscript tradition of those texts demonstrates that some of the lines in these poems in archaic Irish are intertwined with explanatory notes in Latin (given below in bold):

Bresal Brec dā mac leis Condla senathair Ossairge ut de illis post dicemus ocus Lugaid senathair Lagen

(BB 120a 10)

Bresal Brec who has two sons, Connla, the ancestor of the Ossairge about whom we will speak afterwards and $L$. the ancestor of the Leinstermen

Art Mess-Telmann dibad a chlann; is lais con-rotacht Mur nAlinne licet antea ciuitas regalis fuit, ut poeta dixit [...]

(Rawl. B 502 118a29)

Art M.-T., his progeny is destroyed; it is he who built a Wall of A. although previously there was a royal city, as the poet said [...]

In Cathaịr Mār imorro .xxx.iii. meic [lais] ut periti dicunt (BB affirmant). Do-roibdatar a clanna huili acht .x. meic tantum.

(Rawl. B 502 120b51)

C.M. then, [his] 33 sons reported (confirmed) as perished.

All his children perished, except so few as 10 sons.

Cathair Mar .xxx. mac leis; do-roebdatar tantum sed .x. ut periti dicunt. Fiachu ba hAiccid a quo sunt reges Hui Ceinselaig ${ }_{7}$ Hui Dunlainge [...]. Or a ndire enechclainne, de quibus dicitur [...].

(Rawl. B 502 121a19)

C.M., his 30 sons, perished all but ten reported as perished.

F. from whom are the kings of the Uí Chensellaigh and Uí Dunlainge [...]. Gold is the compensation of their honour-price of whom it is said [...].

Nirand iuuenis quando mortuus fuit Connamail mac Cathair de quibus dicitur $[\ldots]$

(Rawl. B 502 124a34)

N. the young, when $C$. m. C. died, of whom it is said $[\ldots]$ 
Quia Luaigne occiderunt eum, ut idem ait [...]

Since L. overthrew him, as the above-mentioned said [...]

Thirdly, we notice a similar pattern in the early Irish glossaries. The ease with which the compiler switches back and forth between Latin and Irish is remarkable. Both the earliest stratum of O'Mulc.'s glossary (perhaps of the seventh century) and the earliest versions of Cormac's glossary contain a high proportion of entries where the technical framework is Latinate even though the words under discussion are Irish.

Nimb .i. bróen. ab eo quod est nimbus. inde dicitur isna Brethaib nemid.

N., i.e., rain, from which there is rain-storm. Thence it is said in the Bretha Nemed.

Beist .i. a bestia ... Bārcc .i. a barca.

B., i.e. from [the word for a] 'beast'... B., i.e. from [the word for a] 'ship'.

Brisc .i. ab eo quod est priscus ar is brisc (cach crīn 7) cach n-arsaid.

B., i.e., from which there is [the word] 'old', for everything withered and everything old is fragile.

(Meyer 1912: 13)

Finally, we can look at the earliest sections of the annals, where one sees some short variation in the use of Irish as opposed to Latin at certain periods with the high proportion of Latin found in the earlier stratum.

Alii libri dicunt Maine filium Neill in isto anno perisse.

(Annals of Ulster 440.2)

Some books state that Maine son of Niall perished this year.

(Mac Airt 1983: 40-1)

Bellum Femhin in quo cecidit filius Coerthin filii Coeboth. Alii dicunt di Chruithnibh fuisse.

(Annals of Ulster 446)

The Battle of Feimen in which the son of Cairthinn son of Caelub fell. Some say he was of the Cruithin.

(Mac Airt 1983: 42-3) 
Mors Ennai mc. Cathbotha 7 natiuitas sancte Brigide ut alii dicunt.

(Annals of Ulster 456)

Death of Énna son of Cathub, and the birth of Brigit, some say.

(Mac Airt 1983: 44-5)

Cena alias feis Temhra apud ${ }^{\text {alias la }}$ Loeghaire filium Neill

(Annals of Ulster 454)

The Feast of Temair [held] by Laegaire son of Niall

(Mac Airt 1983: 44-5)

Cath Atho Dara for Laihaire re Laighnibh in quo 7 ipse captus est, sed tunc dimissus est, iurans per solem 7 uentum se boues eis dimissurum.

(Annals of Ulster 458)

The Battle of Áth Dara [was won] by the Laigin over Laegaire, and in it he himself was taken prisoner, but was then freed on swearing by sun and wind that he would remit to them the cattle-tribute.

(Mac Airt 1983: 46-7)

Mors Laeghaire filii Neill oc Greallaigh Daphil alias oc Greallaigh Ghaifl for taebh Chaisse in Campo Lifi etir in da chnoc, .i. Eiriu 7 Albu a n-anmanda ar ata re Laighnibh gumadh grian ${ }_{7}$ gaeth ros-mharbhsad.

(Annals of Ulster 462)

Death of Laegaire son of Niall, at Grellach Dabhaill or Grellach Ghaifil on the side of Caisse in Magh Life, between two hills called Eiriu and Albu; for the Laihin thought that it was sun and wind that killed him.

(Mac Airt 1983: 42-3)

Cena Temhra la hAilill Molt. Sic in Libro Cuanach inueni.

(Annals of Ulster 467)

The Feast of Temair [held] by Ailill Molt. Thus I have found in the Book of Cuanu.

(Mac Airt 1983: 48-9)

Such recurrent usage of Latin supposes a functioning bilingualism in the medieval Irish scriptorium. Indicative of its status is the use of Latin in the glossaries, genealogies and annals as a medium providing a linking device- or rather, to be precise, as a responsive technical language.

One may even speculate that the compilers used Latin spontaneously. Defined in the linguistic studies of code-switching as "authentic" usage of the language (Grotans 2006: 114), such spontaneous connecting through the medium of Latin of the textual building blocks 
(conveying vernacular topics in the vernacular language) outlines the Latinate-minded linguistic culture of the compilers.

The scribes, for whom it was easier to think in Latin than in Irish, had to re-adjust themselves to thinking in a vernacular, and the process was an evolving one. The fabric of manuscript writing, although filled with native idioms and clauses appropriate for the context, was weaved together using an international linguistic medium which, on the one hand, had a long and culturally pre-eminent pedigree, and on the other - in the context of the developing Christian conversion - was of a higher, more prestigious status.

\section{Conclusion}

In this necessarily short contribution, I have tried to assess historical, lexicographic and textual evidence in relation to the earliest period of the Irish tradition. I have dealt with the matters of contact and exchange between prePatrician Ireland and Roman Britain, noting the movement of peoples, words and languages in both directions. On the basis of the data cited above, I propose that the trade nexus centres ('emporia') were necessarily the focal points where interlinguistic exchange took place in the first instance. Having re-assessed the question of the pre-Patrician borrowings from Latin into Irish, it has become clear that such linguistic items were necessarily limited to the spheres of trade, seafaring and warfare. Turning to Irish/Latin diglossia and code-mixing, the evidence of the first vernacular Irish documents points to the use of Latin as a responsive technical language. Irish scribes were already fluent in Latin, treating it as a spoken rather than a written medium, and it may well be that the first compilers of the early Irish documents gained their fluency from the verbal exchanges of the emporia as well as from their training at the scriptoria. ${ }^{30}$

Furthermore, these sources were compiled by scribes whose Latin was as good as their Irish, ${ }^{31}$ and yet we are dealing with a specific repertoire of genres in which the two languages are equally mixed. It may be that the early scribes prioritised the production of genealogical, annalistic and lexicographic compilations, feeling that providing a reasonable and reliable historical (on the basis of the annals), political (on the basis of the genealogies) and linguistic (on the basis of the glossaries)

\footnotetext{
30 See Bisagni (2014: 54) on the training and education of the medieval scribes with accompanying references.

${ }^{31}$ One may question whether the compilers in question were native or foreign to Ireland; this dichotomy however may not be appropriate in view of the recent study by O'Loughlin (2007) who presented the conversion of Ireland as the undertaking of a single nation.
} 
framework for early Irish learning was of primary importance. ${ }^{32}$ Having thus paid particular attention to the three genres under investigation, these nameless compilers provided the Irish learned circles with the opportunity- from the sixth century onwards - to discover and develop other forms and genres of literary expression in a more elaborate and exquisite way.

Ulster University

\section{References}

Bateson, J. D., 1973, 'Roman Material from Ireland', Proceedings of the Royal Irish Academy 73 (C), 72-3.

Binchy, D. A., 1976, 'Semantic Influence of Latin in the Old Irish Glosses', in: O'Meara, J. \& Naumann, B., eds., Latin Script and Letters. Festschrift Presented to Ludwig Bieler on the Occasion of his 70th Birthday, Leiden: Brill.

Bieler, L., ed. and tr., 1979, The Patrician texts in the Book of Armagh (Scriptores Latini Hiberniae 10), Dublin: Dublin Institute for Advanced Studies.

Bisagni, J., 2014, 'Prolegomena to the Study of Code-Switching in the Old Irish Glosses', Peritia 24-5, 1-58.

Bockius, R., 2011, 'Keltische Schifffahrt - ein historisch-archäologisches Konstrukt?', in: Marquart, M., ed., KeltenLand am Fluss. Die Kelten im Rhein-Main-Gebiet. Museen der Stadt Aschaffenburg Begleitband zur Ausstellung im Schlossmuseum Aschaffenburg vom 15. Mai bis 12. September 2010, Rahden/Westf.: Leidorf, 25-34.

Breatnach, L., 2014, 'Forms of Payment in the Early Irish Law Tracts', Cambrian Medieval Celtic Studies 68/Winter, 1-20.

Brindley, A., \& Lanting, J., 1990, 'A Roman Boat in Ireland'. Archaeology Ireland 4/3, 10-1.

\footnotetext{
32 Bisagni (2014: 15-6) calls our attention to the disparity of the classic diglossic dichotomy 'H(igh) vs. L(ow).' in relation to the standing of Latin in relation to Irish: "while Latin obviously enjoyed a position of international cultural pre-eminence, at the same time Irish seems to have been perceived as an important tool [...] worthy of being employed in a learned context for the production of vernacular literature, as well as for the elucidation of difficult texts." The legend of St. Patrick who is authorising the different branches of vernacular learning to thrive under the auspices of the Church (administered through the linguistic medium of Latin), preserved in the Ps.-Historical Prologue to the Senchas Már, thus may not be far from the truth: "Until Patrick came, speaking was only granted to three men: the historian [...] the man of art [...] the judge for giving judgements [...] After Patrick's coming, however, all of these [...] are subject to the possessor of the white language of the scriptures" (Carey 1994: 19).
} 
Bronner, D., 2005, 'Code-switching in Medieval Ireland: The case of the Vita Tripartita Sancti Patricii', Journal of Celtic Linguistics 9, 1-12.

Carney, J., ed., 1971, 'Three Old Irish Accentual Poems', Ériu 22, 23-80. Charles-Edwards, T., 1998, 'The Context and Uses of Literacy in Early Christian Ireland', in: Pryce, H., ed., Literacy in Medieval Celtic Societies. Cambridge: Cambridge University Press, 62-82.

Charles-Edwards, T., 2000, Early Christian Ireland, Cambridge: Cambridge University Press.

Church, A. J., \& Brodribb, W. J., eds. and trans., 1864-77, Cornelius Tacitus, The Life of Cnceus Julius Agricola, London: Macmillan.

Clackson, J., \& Horrocks, G., 2009, The Blackwell History of the Latin Language, Malden/Oxford/Victoria: Blackwell Publishing.

Corthals, J., 1989, 'Zur Frage des mündlichen oder schriftlichen Ursprungs der Sagen roscada', In Tranter, S. N., and Tristram, H., eds., Mündlichkeit und Schriftlichkeit in der älteren irischen Literatur. Early Irish literature - Media and Communication, Tübingen: Gunter Narr, 201-20.

Corthals, J., 1990, 'Some Observations on the Versification of the Rhymeless "Leinster Poems", Celtica 21, 113-25.

Corthals, J., 1996, 'Early Irish Retoirics and their Late Antique Background', Cambrian Medieval Celtic Studies 31/Summer, 17-36.

Corthals, J., 1999, 'Zur Entstehung der archaischen irischen Metrik und Syntax', in: H. Eichner \& H. Ch. Luschützky, eds., Compositiones Indogermaniae in memoriam Jochem Schindler, Prague: Enigma Corporation, 19-45.

de Bernardo Stempel, P., 2000, 'Ptolemy's Celtic Italy and Ireland: a Linguistic Analysis', in: P. Sims-Williams \& D. N. Parsons, eds., Ptolemy: Towards a Linguistic Atlas of the earliest Celtic Place-names of Europe, Aberystwyth: CMCS Publications, 83-112.

Di Martino, V., 2003, Roman Ireland, Westlink Park u.a.

Dillon, M., 1944, 'Italic and Celtic', The American Journal of Philology, 65/2, 124-134.

Dumville, D. N., 1993, Saint Patrick A.D. 493-1993, Woodbridge: Boydell Press.

Eska, J. F., \& Wallace, R. E., 2001, 'Remarks on the Thematic Genitive Singular in Ancient Italy and Related Matters', Incontri Linguistici 24, 7797.

Fomin, M., 2013, Instructions for Kings. Secular and Clerical Images of Kingship in Early Ireland and Ancient India, Heidelberg: Winter Verlag. Grotans, A., 2006, Reading in Medieval St. Gall, Cambridge: Cambridge University Press. 
Gwynn, E., 1906, The Metrical Dindshenchas, vol. III, Dublin: Royal Irish Academy.

Hamp, E. P., 1996, 'Voteporigis Protictoris', Studia Celtica 30, 293.

Hanson, R. P. C., 1971, 'English Translation of the Confession and the Letter to Coroticus of Saint Patrick', Nottingham Medieval Studies 15, 326.

Harvey, A., 1999, 'Some observations on Celtic-Latin name formation', in: Carey, J., Koch, J., Lambert, P.-Y., eds., Ildánach ildírech: a Festschrift for Proinsias Mac Cana (Celtic Studies Publications 4), Andover, MA: Celtic Studies Publications, 53-62.

Harvey, A., 2011, 'Lexical influences on the Medieval Latin of the Celts', in: Pérez González, M., Pérez Rodríguez, E., eds., Influencias léxicas de otras lenguas en el latín medieval, León, 65-78.

Harvey, A., 2013, 'The Non-Classical Vocabulary of Celtic-Latin Literature: an Overview', in: M. Garrison, A. P. Orban \& M. Mostert (eds.), Spoken and written language: relations between Latin and the vernacular languages in the earlier middle ages, Turnhout: Brepols, 87100.

Ivanov, Vyach. Vs., 1999, 'Comparative Note on Hurro-Urartian, Northern Caucasian, and Indo-European', in: Vine, B., and Ivanov, Vyach. Vs., eds., UCLA Indo-European Studies 1, Los-Angeles: University College of Los Angeles.

Jackson, K., 1953, Language and History in Early Britain, Edinburgh: University Press.

Johnston, E., 2017, 'Ireland in Late Antiquity: A Forgotten Frontier', Studies in Late Antiquity 1.2, 107-23.

Joyce, P. W., 1912, Origin and History of Irish Names of Places, London. Knott, E., 1936, Togail Bruidne Da Derga, Dublin: DIAS.

Lehmann, P., 1968, Mittellateinisches Wörterbuch. II.1: c-canicula, München.

Mac an Bhaird, A., 1991-3, 'Ptolemy Revisited'. Ainm 5, 1-20.

Mac Cana, P., 1976, 'The Latin Influence on British: the Pluperfect', in: O'Meara, J. \& Naumann, B., eds., Latin Script and Letters. Festschrift Presented to Ludwig Bieler on the Occasion of his 70th Birthday, Leiden: Brill.

Mac Cana, P., 2011, The Cult of the Sacred Centre: Essays on Celtic Ideology, Dublin: DIAS.

MacNeill, E., 1931, 'Archaisms in the Ogham Inscriptions', Proceedings of the Royal Irish Academy (C) 39, 33-53.

Matasović, R., 2007, 'Insular Celtic as a Language Area', in: Tristram, H., ed., The Celtic Languages in Contact. Papers from the Workshop 
within the Framework of the XIII International Congress of Celtic Studies, Bonn, 26-27 July 2007, Potsdam: Potsdam University Press, 93-112.

Matasović, R., 2009, Etymological Dictionary of Proto-Celtic, Leiden: Brill.

McCone, K., 1989, 'Zur frage der Register im früheren Irischen', in Tranter, S. N., and Tristram, H., eds., Mündlichkeit und Schriftlichkeit in der älteren irischen Literatur. Early Irish literature - Media and Communication, Tübingen: Gunter Narr, 57-97.

McManus, D., 1983, 'A Chronology of the Latin Loan-Words in Early Irish', Ériu 34, 21-69.

McManus, D., 1991, A Guide to Ogam, Maynooth: An Sagart.

Meyer, K., ed., 1912, 'Sanas Cormaic. An Old-Irish Glossary Compiled by Cormac úa Cuilennáin, King-bishop of Cashel in the Tenth century', in: Bergin, O., Best, R., Meyer, K. and O'Keeffe, J., eds., Anecdota from Irish manuscripts. Vol. 4. Halle and Dublin.

Mohrmann, C., 1962, 'The Earliest Continental Irish Latin', Vigiliae Christianae 16, 216-33.

Nash-Williams, V. E., 1950, The Early Christian Monuments of Wales, Cardiff: University of Wales Press.

Ó Cathasaigh, T., 1984, 'The Déissi and Dyfed', Éigse 20, 1-33.

Ó Cathasaigh, T., 2005, 'The Expulsion of the Déisi', Journal of the Cork Historical and Archaeological Society 110, 13-20.

Ó Cróinín, D., 2004, The First Century of Anglo-Irish Relations, AD 600700, Dublin: The Academic Press.

O'Curry, E., 1873, On the Manners and Customs of the Ancient Irish, Dublin: RIA.

O'Loughlin, T., 2007, 'The Myth of Insularity and Nationality in Ireland', in: Nagy, J. F., ed., Myth in Celtic literatures (CSANA Yearbook 6), Dublin: Four Courts Press, 132-40.

O'Rahilly, T. F., 1946, Early Irish History and Mythology, Dublin.

Picard, J.-M., 2003, 'The Latin Language in Early Medieval Ireland', in: Cronin, M., \& Ó Cuilleanáin, C., eds., The Languages of Ireland. Dublin: Four Courts Press, 44-56.

Pokorny, J., 1954, 'Die Geographie Irlands bei Ptolemaios', Zeitschrift für celtische Philologie 24, 94-120.

Raftery, B., 1994, Pagan Celtic Ireland: The Enigma of the Irish Iron Age, London.

Raftery, B., 1996, 'Drumanagh and Roman Ireland', Archaeology Ireland 10/1, 17-9.

Raftery, B., 2005, 'Iron Age Ireland', in: Ó Cróinín, D., ed., A New History of Ireland. I. Prehistoric and Early Ireland, Oxford: Oxford University Press, 134-81. 
Reinard, P., 2014, 'Arma ultra litora Iuvernae promovimus - Römer in Irland?', in: Drexhage, H.-J., Mattern, T., Rollinger, R., Ruffing, K., Schäfer, C., eds., Marburger Beiträge zur Antiken Handels-, Wirtschaftsund Sozialgeschichte 31, 1-36. Rahden/Westf.: Leidorf, 1-36.

Richards, M., 1960, 'The Irish Settlement in South-West Wales', Journal of the Royal Society of Antiquaries of Ireland 90, 133-62.

Richter, M., 1996, 'The Introduction of Alphabetic Writing to Ireland: Implications and Consequences', in: Klar, K., ed., A Celtic Florilegium: Studies in Honour of Brendan Ó Hehir, Lawrence: Celtic Studies Publications, 152-64.

Ringe, D., Warnow, T., \& Taylor, A., 2002, 'Indo-European and Computational Cladistics', Transactions of the Philological Society 100/1.2, 59-129.

Rolfe, J. C., ed., 1935-1940, Ammianus Marcellinus, Rerum Gestarum, Cambridge, Mass.: Harvard University Press; London: William Heinemann.

Russell, P., 1988, 'The Sounds of a Silence: the Growth of Cormac's Glossary', Cambrian Medieval Celtic Studies 15/Summer, 1-30.

Russell, P., 1990, Celtic Word Formation: The Velar Suffixes, Dublin: DIAS.

Russell, P., 1995, 'Brittonic Words in Irish Glossaries', in: Eska, J., Grufydd, R. G., \& Jacobs, N., eds., Hispano-Gallo-Brittonica, Cardiff: University of Wales Press, 166-82.

Russell, P., 2005, "What was best of every language": The Early History of the Irish Language', in: Ó Cróinín, D., ed., A New History of Ireland. I. Prehistoric and Eearly Ireland. Oxford: Oxford University Press, 405450.

Rynne, E., 1976, 'The La Tène and Roman Finds from Lambay, Co. Dublin', Proceedings of the Royal Irish Academy (C), 76, 231-44.

Schrijver, P., 2016, 'Sound Change, the Italo-Celtic Linguistic Unity, and the Italian Homeland of Celtic'. In: Koch, J. T., \& Cunliffe, B., eds., Celtic from the West 3. Atlantic Europe in the Metal Ages: Questions of Shared Language, Oxford: Oxbow Books, 489-502.

Snyder, C. A., 2003, The Britons, Oxford: Blackwell.

Spaul, J., 2000, Cohors ${ }^{2}$. The Evidence for and a Short History of the Auxiliary Infantry Units of the Imperial Roman Army, Oxford: Archaeopress.

Stevenson, J., 1989, 'The Beginnings of Literacy in Ireland', Proceedings of the Royal Irish Academy 89 (C), 127-165.

Stokes, W., ed., 1860, Irish Glosses: A Mediaeval Tract on Latin Declension, with Examples Explained in Irish, to which are Added The 
Lorica of Gildas with the Gloss thereon, and a Selection of Glosses from the Book of Armagh, London: The Archaeological and Celtic Society.

Stokes, W., 1893, 'The Violent Deaths of Goll and Garb', Revue Celtique 14, 396-449.

Stokes, W., ed. and tr., 1887, The Tripartite Life of Patrick: with Other Documents Relating to that Saint (Rerum Britannicarum Medii Aevi Scriptores 89), London: Eyre and Spottiswoode. 2 vols.

Stokes, W., \& J. Strachan, 1901-3, eds., Thesaurus Palaeohibernicus, Cambridge: Cambridge University Press. 2 Vols.

Toner, G., 1990, 'Identifying Ptolemy's Irish Places and Tribes', in: Sims-Williams, P., \& D. N. Parsons, eds., Ptolemy: Towards a Linguistic Atlas of the earliest Celtic Place-names of Europe, Aberystwyth: CMCS Publications, 73-82.

Vendryes, J., 1913, 'Les formes verbales en -r- du tokharien et de l'italoceltique', Revue Celtique 34, 129-142.

Warner, R. B., 1995, 'Tuathal Techtmar. A Myth or Ancient Literary Evidence for a Roman Invasion?', Emania 13, 23-32.

Weiss, M., 2009, Outline of the Historical and Comparative Grammar of Latin, Ann Arbor: Beech Stave.

Weiss, M., 2012, 'Italo-Celtica: Linguistic and Cultural Points of Contact between Italic and Celtic', in: Jamison, S., Melchert, C., \& Vine, B., eds., Proceedings of the $23^{\text {rd }}$ Annual UCLA Indo-European Conference. Bremen: Hempen Verlag, 151-73. 